\title{
Pengaruh Ruang Publik Terhadap Kualitas Visual JALAN KALI BESAR JAKARTA
}

\author{
Dedi Hantono $^{1 *}$ \\ Program Studi Arsitektur, Universitas Muhammadiyah Jakarta ${ }^{1}$ \\ dedihantono@ftumj.ac.id*
}

\begin{abstract}
Kali Besar is a river that stretches from South to North and there are two roads on both sides, namely: Jalan Kali Besar Barat and Jalan Kali Besar Timur. On the government's awareness of the importance of preservation of buildings and historic areas, since 2008 the City of Jakarta was established as a conservation area and became a tourist destination in Jakarta. Many things have been attempted by the government such as the improvement of public space which is to be one tourist destination for visitors to enjoy the atmosphere of the past. Above it then conducted a study to determine whether the influence of public space for the visual quality of the area, especially Kali Besar. This research uses quantitative method with post positivistic rationalist approach. The result of the research shows that there is influence of public space on visual quality in Kali Besar Jakarta area.
\end{abstract}

Keywords: public space, visual quality, conservation.

\section{PENDAHULUAN}

Jakarta sebagai kota no.1 di Indonesia mengalami perkembangan yang paling pesat baik dari segi ekonomi, jumlah penduduk, maupun arsitekturnya. Begitu banyak gedunggedung baru menciptakan kawasan baru yang lebih moderen. Namun dibalik itu, kawasan dan bangunan lama yang pernah berdiri pada masa sebelum dan awal kemeredekaan serasa telah dilupakan. Banyak bangunan tersebut ditinggalkan sehingga menjadikan kawasan tersebut tidak berfungsi lagi, dan Kawasan Jakarta Kota adalah salah satunya.

Seiring dengan kesadaran akan pentingnya nilai historis bagi perkembangan kota pada masa yang akan datang, pemerintah Provinsi DKI Jakarta telah mengalokasikan dana APBD untuk penataan air Kali Besar, pedesterianisasi sebagian Jalan Kunir dan pencahayaan di sekitar Sunda Kelapa, dan Museum Bahari. Pekerjaan fisik ini sebagian besar adalah penataan infrastruktur dan ruang publik dengan tujuan menciptakan daya tarik dan menciptakan kembali kepercayaan investor utuk menanamkan modal di Kota Tua.

Kawasan yang seyogyanya sudah "matang" dari segi estetika pada masa awal berdiri dengan langgam klasik yang begitu kental tentu menjadi prioritas utama dalam acuan menata kembali ruang publik pada kawasan tersebut. Dari program pemerintah tersebut dampak apakah yang dapat dirasakan bagi lingkungannya? Apakah pengaruh ruang publik yang ada terhadap kualitas visual di Jalan Kali Besar Jakarta? Untuk menjawab pertanyaan tersebut perlu dilakukan penelitian dengan berdasarkan teori/pustaka yang sesuai.

Untuk membatasi penelitian sehingga dapat lebih terfokus pada inti permasalahan penelitian maka penelitian ini hanya melingkupi pada beberapa hal berikut :

A. Lingkup Substansial.

Lingkup penelitian ini hanya terkait pada hal-hal arsitektur saja terutama ruang publik. Sedangkan bagian-bagian lainnya menjadi pelengkap dan memperkaya hasil penelitian.

B. Lingkup Spasial.

Lokasi penelitian berada di sepanjang koridor Jalan Kali Besar Barat dan Kali Besar Timur yang terletak pada Provinsi DKI Jakarta, Wilayah Kota Jakarta Barat, Kecamatan Tambora, dan Kelurahan Roa Malaka. 


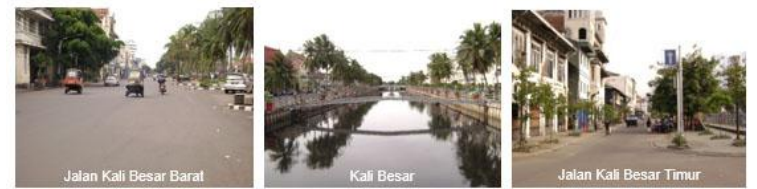

Gambar 1. Gambaran Umum Jalan Kali Besar Barat, Kali Besar, dan Jalan Kali Besar Timur

\section{KAJIAN PUSTAKA}

\section{Teori Ruang Publik}

Menurut Rustam Hakim dalam Dedi Hantono (2013) ruang publik adalah ruang yang terbentuk karena adanya kebutuhan akan perlunya suatu tempat untuk bertemu atau berkomunikasi antara satu manusia dengan manusia lainnya (Hantono, 2013). Menurut Carr bahwa ruang publik adalah suatu tempat dimana terjadinya kehidupan secara bersama. Jalan, lapangan, dan taman kota ikut memberi bentuk dari pasang-surutnya kehidupan manusia (Carr, 1992). Sedangkan menurut Rob Krier, mengartikan ruang publik suatu ruang yang berada diantara bangunan-bangunan perkotaan maupun daerah. Disini Krier lebih senang menyebutkan ruang publik sebagai ruang kota (Krier, 1979).

\section{Prinsip Perancangan Ruang Publik}

Prinsip perancangan Rustam Hakim dalam Dedi Hantono (2013) adalah dasar dari terwujudnya suatu ciptaan bentuk. Bentuk itu sendiri terdiri dari beberapa unsur atau elemen yang masingmasing memiliki sifat dan karakter tersendiri. Untuk menyatukan hal tersebut diperlukan prinsip desain yang matang, yaitu: keteraturan (consistency) dan kesatuan (unity). Keteraturan diperoleh melalui pendekatan tema rancangan sedangkan kesatuan melalui penyederhanaan unsur serta memperkecil perbedaan antar sesama unsur-unsur tersebut.

Untuk mencapai keteraturan dan kesatuan tersebut perlu diperhaikan beberapa hal yang harus dicapai, diantaranya :

1. Keseimbangan (Balance).

Penyamaan tekanan visual suatu komposisi antara masing-masing unsur, diantaranya:

a. Keseimbangan simetris.

Unsur-unsur disusun dalam komposisi yang sama antara kedua sisi. Keseimbangan dalam bentuk ini bersifat statis, formal, kaku, agung, dll.

b. Keseimbangan asimetris.

Unsur-unsur disusun dalam komposisi yang tidak sama namun tetap dalam prinsip rancangan yang baik.
Keseimbangan dalam bentuk ini lebih bersifat dinamis, gerak, spontan, informal (santai), dll.

c. Keseimbangan memusat.

Keseimbangan ini memberikan kesan gerak ke satu titik.

2. Irama dan Pengulangan (Rhytm and Repetition).

Irama adalah pengulangan unsur yang dipergunakan pada tempat yang berbeda dan membentuk ikatan atau hubungan visual. Dalam perancangan ruang luar, irama diperoleh melalui :

a. Garis, yaitu suatu rupa yang menghubungkan 2 buah titik.

b. Bentuk, yaitu wujud suatu benda, baik dalam 2 dimensi maupun 3 dimensi.

c. Tekstur, yaitu kualitas permukaan suatu bidang (halus-kasar).

d. Ruang, yaitu suatu wadah dimana objek dan kejadian tertentu berada. Secara fisik ruang dibentuk oleh 3 elemen dasar, yaitu : alas, dinding, atap.

e. Warna, yaitu corak/intensitas permukaan suatu bentuk. Warna merupakan atribut yang paling mencolok yang membedakan suatu bentuk dengan lingkungannya. (Budihardjo, 2009)

3. Penekanan dan Aksentuasi (Emphasis).

Penekanan dapat diartikan suatu upaya untuk menonjolkan salah satu komponen agar tampak terlihat lebih menonjol dibandingkan komponen lainnya (dominasi).

\section{Teori Kualitas Visual}

Menurut Cullen dalam Darmawan (2005) karakter visual yang menarik adalah karakter formal yang dinamis dapat dicapai melalui pandangan yang menyeluruh berupa suatu amatan berseri atau menerus (serial vision) yang memiliki unit visual yang dominasinya memiliki keragaman dalam suatu kesinambungan yang terpadu dan berpola membentuk satu kesatuan yang unik (Darmawan, 2005). Sedangkan perancangan kota merupakan bagian dari proses perencanaan dalam bentuk rancangan yang berkaitan dengan kualitas fisik spasial dari suatu lingkungan. Perancangan kota mendasarkan pada segi-segi kualitas fisik, salah satunya adalah kualitas visual (Shirvani, 1985).

Tanda-tanda visual adalah ciri-ciri utama yang secara fisik dapat dilihat yang dapat memberikan atribut pada sumber visual dalam 
suatu sistem visual sehingga sistem visual tersebut mempunyai kualitas tertentu (Smardon, 1986). Aspek visual begitu pentingnya di dunia arsitektur sehingga disebutkan bahwa arsitektur itu adalah seni visual. Karena arsitektur merupakan hasil karya yang dapat dinikmati dengan sensasi langsung pada mata (Halim, 2005). Menurut Clive Bell dalam Andry Masri (2010), kualitas visual adalah keindahan yang dirasakan oleh seseorang berdasarkan pengalamannya sehingga dapat mengenali suatu wujud yang bermakna dalam suatu benda tertentu dengan getaran atau rangsangan keindahan (Masri, 2010).

\section{Teori Pemilihan Indikator Kualitas Visual}

Smardon (1986) mengatakan bahwa nilai visual suatu kawasan ditunjukkan oleh adanya kualitas fisik yang terbentuk oleh hubungan atau interelasi antar elemen-elemen visual pada suatu lansekap kota. Dengan kriteria penilaian sebagai berikut :

a. Keragaman (Diversity).

Kumpulan dari berbagai elemen pola serta susunan yang bervariasi.

b. Dominasi (Dominant).

- Kendali : kuasa : utama : mempengaruhi.

- Satu dari dua bagian yang berbeda harus jelas mendominasi yang lain.

c. Keharmonisan (Harmony).

Tampilan dari seluruh bagian yang berbeda menjadi satu kesatuan.

d. Keutuhan (Intactness).

Kesinambungan pandangan dan dalam arti luas adalah bebas dari halangan pandangan.

e. Urutan (Sequence).

Unit-unit disusun berdasarkan urutan dari satu unit ke unit yang lain dengan pola-pola tertentu.

f. Keunikan (Uniqueness).

Sumber visual, karakter visual, atau kualitas visual yang jarang atau tidak biasa ditemukan pada skala daerah atau nasional.

g. Kesatuan (Unity).

- Harmoni pada seluruh pandangan.

- Kesesuaian antar elemen-elemen lansekap.

\section{Landasan Teori dan Hipotesa}

\section{Landasan Teori}

Landasan teori pada penelitian ini didasarkan kepada grand theory yang mengacu kepada perancangan ruang publik dan kualitas visual. Berkenaan dengan ruang publik digunakan teori prinsip perancangan dari Rustam Hakim, yaitu :
Balance (simetri, asimetri, memusat), Rhytm (garis, bentuk, tekstur, ruang, dan warna), dan Emphasis, sedangkan kualitas visual ini menggunakan prinsip-prinsip yang dikemukakan oleh Smardon (1986), yaitu : keragaman (diversity), dominasi (dominant), keharmonisan (harmony), keutuhan (intactness), urutan (sequence), keunikan (uniquenes), dan kesatuan (unity). Prinsip-prinsip ini dapat dipergunakan untuk menilai suatu kualitas visual dalam konteksnya dengan ruang publik.

\section{Hipotesa}

Hipotesa adalah suatu kesimpulan yang belum sempurna karena masih memerlukan pembuktian lebih lanjut. Sesuai dengan tujuan semula penelitian ini, yaitu untuk membuktikan adanya pengaruh ruang publik terhadap kualitas visual pada ruas jalan Kali Besar Jakarta dan berdasarkan kajian awal dari pustaka yang ada maka dapat digambarkan hubungan antara ruang publik dan kualitas visual seperti pada (Gambar 2).

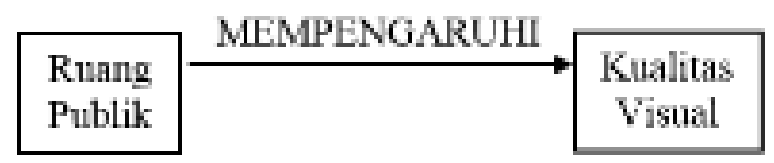

Gambar 2. Bentuk hubungan antara ruang publik dan Kualitas Visual

\section{METODE PENELITIAN}

Pentingnya metode penelitian bagi sebuah penelitian berdampak pada keberhasilan suatu penelitian. Pendekatan yang digunakan dalam penelitian ini adalah post positivistik rasionalistik yang didasarkan pada paradigma kuantitatif (deduktif) dengan tujuan untuk pembuktian teori. Dalam penelitian ini diungkapkan hipotesis yang akan diuji kebenarannya dan dilakukan pemaknaan berdasarkan kepada teori yang digunakan.

Data-data dalam penelitian didapatkan melalui survey lapangan, sampel, dan analisis. Penelitian ini tidak sekedar membuktikan hipotesa, namun juga melakukan pemaknaan terhadap hasil penelitian berdasarkan pada teori yang digunakan.

\section{Tahapan Penelitian}

Tahapan pada penelitian ini terdiri dari 4 langkah, yaitu : 
a. Tahap persiapan: melakukan observasi awal, kajian pustaka, menentukan sampel, dan mendesain kuisioner.

b. Tahap pengumpulan data: observasi lanjut dan angket (kuisioner).

c. Tahap analisis dan temuan penelitian.

d. Tahap penarikan kesimpulan, pemaknaan dan penyusunan rekomendasi.

\section{Populasi dan Sampel Penelitian}

Populasi adalah sejumlah variabel yang mnyangkut permasalah yang dihadapi manusia. Permasalahan dalam hal ini adalah masalah yang sedang diteliti (Rafi'i, 1981). Dari pengertian tersebut populasi yang diambil adalah kelompok manusia yang menggunakan ruang publik pada ruas Jalan Kali Besar Barat dan Jalan Kali Besar Timur. Dalam melaksanakan penelitian, walaupun jumlah populasinya terbatas (terukur) namun adakalanya peneliti tidak mengikutsertakan seluruh populasi dalam penelitian. Populasi yang diambil dan dianggap mewakili penelitian inilah yang disebut sampel.

Dalam penelitian ini peneliti mengambil sampel atas beberapa kelompok, diantaranya :

1. Sampel Kasus.

Dalam hal ini yang menjadi obyek penelitian adalah ruang publik yang berada di Jalan Kali Besar Barat dan Jalan Kali Besar Timur. Dari hasil pengamatan peneliti terdapat 14 obyek ruang publik yang bisa dijadikan bahan penelitian, diantaranya :

1. Jalan Kali Besar Barat.

2. Jalan Kali Besar Timur.

3. Jalur pedestrian Jalan Kali Besar Barat.

4. Arkade.

5. Jalur Pedesterian Jalan Kali Besar Timur (sisi kali)

6. Jalur Pedesterian Jalan Kali Besar Timur (sisi bangunan).

7. Kali Besar.

8. Area Parkir.

9. Area Taman.

10. Area Serbaguna.

11. Bangku Taman.

12. Lampu Hias.

13. Pot Tanaman.

14. Pagar Pembatas Kali.

2. Sampel Pengamat.

Selain dari teori yang terdapat dalam kajian pustaka, untuk mendapatkan nilai kualitas visual dari obyek penelitian diperlukan juga pendapat dari orang-orang yang menggunakan ruang publik tersebut (responden). Setiap segmen terdiri dari 15 responden sehingga diperlukan sebanyak 210 responden.

3. Sampel Waktu Observasi.

Oleh karena obyek yang diamati berupa fisik ruang publik maka waktu pengamatan dapat dilakukan kapan saja. Namun untuk mendapatkan hasil yang lebih akurat, peneliti mengambil waktu pada akhir pekan. Karena pada waktu tersebut banyak pengunjung yang mendatangi lokasi tersebut.

\section{Variabel Penelitian}

Pengertian variabel menurut Bungin (2005) adalah fenomena-fenomena yang bervariasi dalam bentuk, kualitas, kuantitas, mutu, standar, dan sebagainya. Variabel diartikan sebagai konsep yang lebih konkret, yang acuanacuannya secara relatif mudah diidentifikasikan dan diobservasi serta dengan mudah diklasifikasi, diurut, atau diukur (Bungin, 2005). Lain halnya menurut Suryatna Rafi'i (1981), variabel adalah ukuran sifat atau ciri yang dimiliki oleh anggota-anggota suatu kelompok yang berbeda dengan yang dimiliki oleh kelompok yang lain.

Adapun variabel-variabel yang terdapat dalam penelitian ini adalah :

a. Variabel Bebas, yaitu variabel yang berada ada posisi yang lepas dari pengaruh variabel tergantung. Dalam hal ini variabel bebasnya adalah RUANG PUBLIK.

b. Variabel Terikat, yaitu variabel yang dipengaruhi oleh variabel bebas. Dalam hal ini variabel terikatnya adalah KUALITAS VISUAL.

\section{Teknik Penelitian}

Langkah-langkah dalam menganalisis data yang akan dilakukan adalah:

a. Mengumpulkan dan mengelompokkan data yang dibutuhkan, yaitu berbagai elemen ruang publik di sepanjang koridor jalan dalam pengaruh terbentuknya kualitas visual.

b. Analisis data yang telah didapatkan dengan mengambil sampel pada masing-masing elemen ruang publik tersebut dan melakukan penilaian berdasarkan pada indikator sebagai tolok ukur penelitian yang dituangkan dalam kuesioner.

Dalam menganalisa hubungan antara ruang publik dan kualitas visual digunakan analisa 
korelasi untuk menguji dan menjawab hipotesa yang berbentuk asosiatif (korelasi). Sedangkan teknik korelasi menggunakan teknik regresi.

\section{Lokasi Penelitian}

Wilayah studi adalah ruas Jalan Kali Besar Barat dan Jalan Kali Besar Timur yang terletak di Jakarta. Lokasi ini secara administratif masih berada dalam wilayah Kotamadya Jakarta Barat walaupun letaknya lebih condong ke arah Utara Kota Jakarta atau lebih tepatnya berada pada Kawasan Jakarta Kota yang merupakan kawasan konservasi dan revitalisasi.

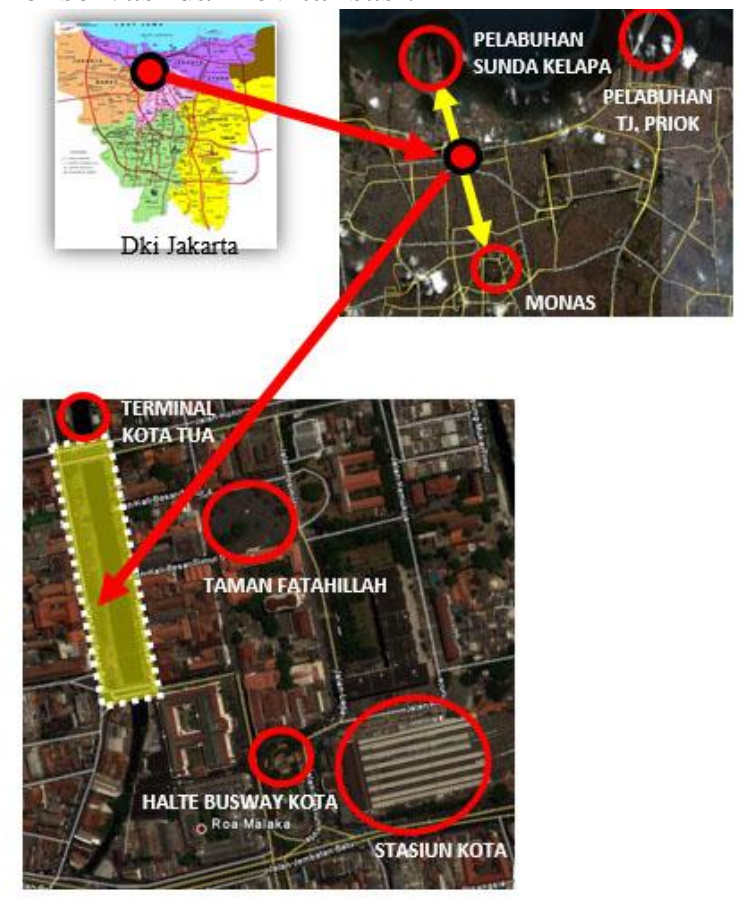

Gambar 3. Keyplan Kawasan Jakarta Kota

Objek penelitian adalah ruang publik yang berada pada ruas Jalan Kali Besar yang dibelah oleh sebuah kali yaitu Kali Besar. Kali ini membelah jalan tersebut menjadi 2 buah ruas jalan yang terletak pada sisi Barat dan sisi Timur sehingga menjadi Jalan Kali Besar Barat dan Jalan Kali Besar Timur.

\section{HASIL DAN PEMBAHASAN}

Responden penelitian sebanyak 210 orang yang dibagi atas 14 segmen. Karakteristik responden ditinjau dari 11 kategori, yaitu : (1) lokasi tempat tinggal, (2) jenis kelamin, (3) status pernikahan, (4) Kelompok usia (5) status pekerjaan, (6) tingkat pendidikan, (7) frekuensi kedatangan, (8) alat kedatangan, (9) orang yang menyertai, (10) tujuan, (11) sumber info tentang lokasi.

\section{Deskripsi Hasil Kuesioner}

Setelah dilakukan proses analisis data dari hasil kuesioner maka didapat komposisi jawaban responden yang terdiri dari 5 skala jawaban (Skala Likert), yaitu : sangat setuju (ss), setuju (s), biasa saja (bs), tidak setuju (ts), dan sangat tidak setuju (sts).

\section{Pengujian Hipotesis}

Pengujian hipotesis pada penelitian ini untuk menguji pengaruh ruang publik terhadap kualitas visual pada ruas Jalan Kali Besar Barat dan Jalan Kali Besar Timur di Jakarta. Adapun uji hipotesis yang digunakan adalah dengan menggunakan Uji t dua sisi (two tailed) dengan tingkat signifikansi 0,05 . Setelah dilakukan pengolahan data hasil kuesioner dengan menggunakan bantuan program komputer SPSS versi 17 maka hasilnya dapat dilihat pada Lampiran Uji Hipotesa di halaman terakhir pada tulisan ini.

Nilai Pengaruh Variabel Bebas Terhadap Variabel Terikat dari Segmen yang Terpilih Dari pengujian hipotesa di atas ternyata tidak semua variabel bebas, dalam hal ini Ruang Publik yang ikut memengaruhi Kualitas Visual sebagai variabel terikat. Dari 14 segmen yang ada, hanya 5 segmen yang memiliki faktor pengaruh terhadap variabel terikat., diantaranya : Jalan Kali Besar Barat, Jalan Kali Besar Timur, Kali Besar, Jalur Pedesterian Jalan Kali Besar Timur (sisi bangunan), dan Area Serbaguna, dengan nilai pengaruh masing-masing yang berbeda.

\section{TEMUAN PENELITIAN}

Setelah analisa data kuesioner dilakukan maka ditemukan peran masing-masing indikator terhadap kualitas visual yang terjadi pada ruang publik yang terdapat pada ruas Jalan Kali Besar. Ada beberapa temuan yang didapat dari hasil jawaban para responden yang dibahas dalam sub bab berikutnya.

\section{Peran Elemen Pembentuk Ruang Publik pada Lokasi Penelitian}

Dilihat dari jawaban responden peran simetri ini sangat dirasakan pada ruang publik yang berbentuk jalan/koridor namun dengan dimensi yang sangat lebar (mendominasi). Hal ini dapat dimengerti karena bentuk yang seperti itu lebih nyata dan mudah dalam persepsi sebuah bentuk yang simetri. Jadi jelas, faktor sumbu (ruang publik) dalam hal ini erat kaitannya dengan 
kualitas visual (dominasi) yang ada pada lokasi penelitian.

Faktor Asimetri lebih cenderung sebagai faktor yang dinamis, spontan, dan kesan bergerak. Hal ini tidak ada satupun yang dirasakan pada ruang publik. Padahal seharusnya untuk area rekreasi, faktor dinamis, spontan, dan kesan bergerak sangat perlu ditampilkan. Mungkin hal ini kesan area kota tua (kolonial) yang bersifat kaku, formal, dan statis, masih sangat kental dirasakan oleh responden.

Faktor memusat banyak dirasakan pada ruang publik : Jalan Kali Besar Timur (66,67\% setuju), Kali Besar (53,33\% setuju), Jalur Pedesterian Jalan Kali Besar Barat (53,33\% setuju). Sama halnya dengan faktor Simetri, faktor Memusat banyak dirasakan pada ruang publik yang berbentuk memanjang (koridor). Hal ini sejalan dengan teori Rustam Hakim bahwa suatu garis yang bergerak menuju ke satu titik.

Pada ruang publik yang berbentuk ruang terbuka, kesan garis banyak dirasakan pada ruang publik yang berbentuk memanjang (koridor). Garis dalam hal ini dirasakan oleh responden sebagai suatu sumbu pembentuk ruang. Sedangkan pada ruang publik yang berbentuk benda (street furniture) garis adalah elemen pembentuk obyek itu sendiri. Hal ini dapat dilihat pada bangku taman yang terdiri dari baris kayu yang berbentuk memanjang sehingga membentuk elemen garis horisontal. Kemudian Lampu Hias yang berbentuk tiang yang tinggi sehingga terlihat sebagai elemen garis vertikal. Dan Pagar Pembatas Kali yang terdiri dari besi memanjang yang disusun secara horizontal sangat terlihat dan dirasakan oleh responden.

Peran bentuk yang paling banyak dirasakan oleh responden pada ruang publik : Kali Besar (53,33\% setuju), Jalur Pedesterian Jalan Kali Besar Barat (60\% setuju), Jalur Pedesterian Jalan Kali Besar Timur (sepanjang sisi bangunan) sebesar $60 \%$ setuju, Bangku Taman (53,33\% setuju), Pagar Pembatas Kali $(46,67 \%$ setuju).

Dilihat dari besar persentase jawaban responden kesan Tekstur banyak dirasakan pada kedua jalan yang ada pada lokasi penelitian. Hal ini karena bahan pembentuk jalan yang terbuat dari aspal adalah suatu bahan yang biasa untuk membentuk jalan sehingga tanpa merabanya secara langsung pun para responden sudah dapat merasakan kualitas tekstur tersebut.

Namun yang menjadi menarik perhatian adalah Area Serbaguna juga sangat dirasakan faktor teksturnya oleh responden. Hal ini dimungkinkan karena area ini adalah area yang paling banyak didatangi oleh para rsponden karena area ini menjadi sumber kegiatan pada lokasi penelitian sehingga banyak responden yang berinteraksi langsung dengan area ini.

Peran Ruang yang paling banyak dirasakan responden pada Arkade karena pada Arkade jelas sekali batas ruangnya, yaitu memiliki lantai, dinding dan atap. Sedangkan ruang-ruang yang lain bersifat ruang maya.

Tidak ada satupun ruang publik faktor Warna yang dirasakan oleh para responden. Hal ini dimungkinkan masih kentalnya nuansa kolonial yang identik dengan warna putih, dingin, dan kaku. Faktor ini sama nasibnya dengan faktor Asimetri.

Peran Penekanan yang paling banyak dirasakan responden pada ruang publik adalah : Jalan Kali Besar Timur (53,33\% setuju), Area Taman (46,67\% setuju), Area Serbaguna (60\% setuju), dan Bangku Taman (53,33\% setuju).

\section{Peran Kualitas Visual pada Penelitian}

Peran Diversity hanya dirasakan oleh responden sebagai pembentuk kualitas visual pada Area Parkir yaitu sebesar 53,33\% berpendapat setuju. Hal ini dirasakan karena pola parkir yang ada lebih dari 1 macam, yaitu tegak lurus dan serong $45^{\circ}$ terhadap badan jalan.

Peran Dominant yang paling banyak dirasakan responden sebagai pembentuk kualitas visual pada ruang publik adalah : Kali Besar (53,33\% sangat setuju) dan Area Serbaguna (73,33\% setuju).

Simetri dan Garis menjadi elemen berpengaruh terhadap kualitas visual pada faktor keharmonisan. Bentuk simetri menjadi faktor yang dapat membentuk suatu obyek menjadi bentuk yang teratur dan harmonis. Sedangkan elemen garis yang teratur turut pula membentuk keharmonisan suatu obyek yang didapat.

Peran Intactnes hampir dirasakan pada seluruh elemen pembentuk ruang public. Karena hampir seluruh elemen ruang publik yang ada masih dalam keadaan utuh atau dapat terlihat secara utuh. 
Peran Sequence dapat dirasakan oleh responden sebagai pembentuk kualitas visual pada ruang publik hanya pada Pagar Pembatas Kali yaitu sebesar $66,67 \%$ memberikan jawaban setuju. Karena bentuk pagar tersebut paling mudah dikenali dari pola urutan yang sama dan berulang-ulang.

Peran Uniquenes yang paling banyak dirasakan responden sebagai pembentuk kualitas visual pada ruang publik adalah : Jalan Kali Besar Barat (60\% setuju) dan Kali Besar (46,67\% setuju).

Peran Unity yang paling banyak dirasakan responden sebagai pembentuk kualitas visual pada ruang publik adalah : Jalan Kali Besar Barat $(86,67 \%$ sangat setuju), Jalan Kali Besar Timur (66,67\% setuju), Kali Besar (53,33\% sangat setuju), Arkade (53,33\% sangat setuju), Jalur Pedesterian Jalan kali Besar Timur (sepanjang sisi bangunan) sebesar $80 \%$ sangat setuju, Area Serbaguna (73,33\% sangat setuju), dan Lampu Hias (53,33\% setuju).

\section{KESIMPULAN DAN SARAN}

\section{Kesimpulan}

Setelah dilakukan olah data hasil kuesioner dan berdasarkan kajian pustaka maka yang terjadi pada lokasi penelitian bahwa ruang publik mempengaruhi kualitas visual. Oleh karena itu tujuan penelitian ini terdapat kesimpulan bahwa:

"Ada pengaruh ruang publik terhadap kualitas visual pada ruas Jalan Kali Besar di Jakarta."

Namun tidak semua ruang publik ikut mempengaruhi kualitas visual. Dari 14 segmen ruang publik yang ada hanya 5 segmen yang mempengaruhi kualitas visual walaupun besarnya pengaruh tidak sama pada masingmasing segmen tersebut. Adapun ruang publik yang mempengaruhi kualitas visual diantaranya adalah :

1. Jalan Kali Besar Barat, dengan pengaruh sangat kuat.

2. Jalan Kali Besar Timur, dengan pengaruh sedang.

3. Kali Besar, dengan pengaruh sangat kuat.

4. Jalur Pedesterian Jalan Kali Besar Timur (sisi bangunan), dengan pengaruh kuat.

5. Area Serbaguna, dengan pengaruh kuat.

Prinsip perancangan ruang publik yang dikemukakan oleh Rustam Hakim adalah : balance (simetri, asimetri, dan memusat), rhytm (garis, bentuk, tekstur, ruang, dan warna), dan emphasis, adalah tidak sepenuhnya benar pada kasus penelitian ini. Hal ini ini dapat dilihat dari jawaban responden yang tidak merasakan adanya faktor asimetri dan warna pada ruang publik yang ada di ruas Jalan Kali Besar Jakarta.

Smardon (1986) berpendapat bahwa nilai visual suatu kawasan ditunjukkan oleh adanya kualitas fisik yang terbentuk oleh hubungan atau interelasi antar elemen-elemen visual pada suatu lansekap kota. Dengan kriteria penilaian sebagai berikut : diversity, dominant, harmony, intactness, sequence, uniqueness, dan unity. Keseluruhan faktor ini dapat dirasakan pada kualitas visual ruang publik, terutama unity. Hampir keseluruhan ruang publik yang ada faktor unity ini dapat dirasakan oleh para responden. Hal ini berarti mayoritas ruang publik mempengaruhi kualitas visual terutama pada faktor unity tersebut.

\section{Saran}

Dari pemaknaan dan kesimpulan di atas dapat dibuat suatu saran atau rekomendasi yang ditujukan kepada :

1. Pemerintah \& Investor

a. Peran faktor Warna kurang dapat dirasakan oleh sebagian responden sehingga faktor tersebut tidak dapat mempengaruhi kualitas visual yang ada. Padahal faktor ini sangat penting dalam menghidupkan suasana rekreasi yang merupakan tujuan dari lokasi penelitian ini. Untuk itu perlu dibuat pewarnaan yang baik namun tetap tidak merusak nuansa kolonial sebagai faktor unity (kesatuan) dari ruang publik yang ada.

b. Peran Asimetri sebagai faktor pemberi kesan dinamis, spontan, dan bergerak juga kurang dirasakan sebagai elemen pembentuk dari ruang publik. Untuk itu perlu dilakukan upaya perubahan bentuk elemen ruang publik yang lebih dinamis atau membuat area bermain atraktif sehingga para pengunjung tidak hanya bersifat statis ketika berada dalam lokasi penelitian ini.

c. Faktor keragaman juga masih kurang dirasakan pada kualitas visual yang dirasakan oleh responden. Untuk itu perlu suatu elemen-elemen tambahan atau inovasi baru sehingga keragaman dapat terbentuk secara visual.

d. Dilihat dari kelima segmen tersebut di atas, tidak ada satupun ruang publik yang berasal dari street furniture (bangku 
taman, lampu hias, pot tanaman, dan Sons. pagar pembatas kali). Untuk itu perlu untuk mendapat perhatian lebih terhadap pemegang kebijaksanaan dalam hal ini pemerintah untuk menata street furniture yang lebih baik lagi.

2. Akademisi

a. Setelah melakukan penelitian dampak pengaruh ruang publik terhadap kualitas visual pada ruas Jalan Kali Besar Jakarta, peneliti merasa penelitian ini dapat dilakukan lebih lanjut. Ada beberapa fenomena yang belum terjawab pada lokasi penelitian ini, seperti : fasad bangunan, image kota, dll.

b. Selain itu, ruang publik yang diteliti bukan saja dapat dilakukan pada ruas Jalan Kali Besar Barat Jakarta namun pada lokasi-lokasi lainnya. Untuk menghemat waktu, peneliti lainnya dapat menjadikan penelitian ini sebagai acuan untuk penelitian berikutnya.

\section{REFERENSI}

Budihardjo, E. (2009). Kota Berkelanjutan (Sustainable City). Bandung: Alumni.

Bungin, B. (2005). Metode Penelitian Kuantitatif. Jakarta: Kencana Prenada Media Group.

Carr, S. (1992). Public Space. New York: Cambridge University Press.

Darmawan, E. (2005). Analisa Ruang Publik Arsitektur Kota. Semarang: Penerbit Universitas Diponegoro.

Halim, D. (2005). Psikologi Arsitektur Pengantar Kajian Lintas Disiplin. Jakarta: Grasindo.

Hantono, D. (2013). Pengaruh Ruang Terbuka Terhadap Kinerja Pegawai. Pengaruh Ruang Terbuka Terhadap Kinerja Pegawai, 12(2), 1-12. https://doi.org/https://doi.org/10.24853/na lars. $12.2 . \% 25 \mathrm{p}$

Krier, R. (1979). Urban Space. New York: Rizzoli.

Masri, A. (2010). Strategi Visual. Yogyakarta: Jalasutra.

Rafi'i, S. (1981). Metode Statiska Analisis. Bandung: Binacipta.

Shirvani, H. (1985). The Urban Design Process. New York: Van Nostrand Reinhold Company.

Smardon, R. C. (1986). Foundation For Visual Project Analysis. Kanada: John Wiley \& 
Lampiran Uji Hipotesa

\begin{tabular}{|c|c|c|c|c|c|c|c|}
\hline $\begin{array}{l}\text { Ruang } \\
\text { Publik }\end{array}$ & $\mathrm{R}$ & $\mathrm{R}^{2}$ & Siqnifikansi & t tabel & t hitung & \multicolumn{2}{|c|}{ Hipotesis } \\
\hline $\begin{array}{c}\text { Segmen } \\
1\end{array}$ & 0,850 & 0,722 & 0,000 & 2,160 & 5,808 & $\begin{array}{l}\mathrm{t} \text { tabel }<\mathrm{t} \text { hitung } \\
=\text { Ho ditolak }\end{array}$ & $\begin{array}{l}\text { Ada pengaruh } \\
\text { Ruang Publik } \\
\text { terhadap Kualitas } \\
\text { Visual }\end{array}$ \\
\hline $\begin{array}{c}\text { Segmen } \\
2\end{array}$ & 0,581 & 0,337 & 0,023 & 2,160 & 2,571 & $\begin{array}{l}\mathrm{t} \text { tabel }<\mathrm{t} \text { hitung } \\
=\text { Ho ditolak }\end{array}$ & $\begin{array}{l}\text { Ada pengaruh } \\
\text { Ruang Publik } \\
\text { terhadap Kualitas } \\
\text { Visual }\end{array}$ \\
\hline $\begin{array}{c}\text { Segmen } \\
3\end{array}$ & 0,873 & 0,763 & 0,000 & 2,160 & 6,465 & $\begin{array}{l}\mathrm{t} \text { tabel }<\mathrm{t} \text { hitung } \\
=\text { Ho ditolak }\end{array}$ & $\begin{array}{l}\text { Ada pengaruh } \\
\text { Ruang Publik } \\
\text { terhadap Kualitas } \\
\text { Visual }\end{array}$ \\
\hline $\begin{array}{c}\text { Segmen } \\
4\end{array}$ & 0,192 & 0,037 & 0,493 & $-2,160$ & $-0,705$ & $\begin{array}{c}-\mathrm{t} \text { tabel }<-\mathrm{t} \\
\text { hitung }=\mathrm{Ho} \\
\text { diterima }\end{array}$ & $\begin{array}{l}\text { Tidak ada } \\
\text { pengaruh Ruang } \\
\text { Publik terhadap } \\
\text { Kualitas Visual }\end{array}$ \\
\hline$\underset{5}{\text { Segmen }}$ & 0,438 & 0,192 & 0,102 & 2,160 & 1,757 & $\begin{array}{l}\mathrm{t} \text { tabel }>\mathrm{t} \text { hitung } \\
=\text { Ho diterima }\end{array}$ & $\begin{array}{l}\text { Tidak ada } \\
\text { pengaruh Ruang } \\
\text { Publik terhadap } \\
\text { Kualitas Visual }\end{array}$ \\
\hline $\begin{array}{c}\text { Segmen } \\
6\end{array}$ & 0,138 & 0,019 & 0,623 & $-2,160$ & $-0,504$ & $\begin{array}{c}-\mathrm{t} \text { tabel }<-\mathrm{t} \\
\text { hitung }=\mathrm{Ho} \\
\text { diterima }\end{array}$ & $\begin{array}{l}\text { Tidak ada } \\
\text { pengaruh Ruang } \\
\text { Publik terhadap } \\
\text { Kualitas Visual }\end{array}$ \\
\hline $\begin{array}{c}\text { Segmen } \\
7\end{array}$ & 0,776 & 0,603 & 0,001 & 2,160 & 4,443 & $\begin{array}{l}\mathrm{t} \text { tabel }<\mathrm{t} \text { hitung } \\
\quad=\text { Ho ditolak }\end{array}$ & $\begin{array}{l}\text { Ada pengaruh } \\
\text { Ruang Publik } \\
\text { terhadap Kualitas } \\
\text { Visual }\end{array}$ \\
\hline $\begin{array}{c}\text { Segmen } \\
8\end{array}$ & 0,154 & 0,024 & 0,585 & 2,160 & 0,561 & $\begin{array}{l}\mathrm{t} \text { tabel }>\mathrm{t} \text { hitung } \\
=\text { Ho diterima }\end{array}$ & $\begin{array}{l}\text { Tidak ada } \\
\text { pengaruh Ruang } \\
\text { Publik terhadap } \\
\text { Kualitas Visual }\end{array}$ \\
\hline $\begin{array}{c}\text { Segmen } \\
9\end{array}$ & 0,374 & 0,140 & 0,169 & $-2,160$ & $-1,456$ & $\begin{array}{c}-\mathrm{t} \text { tabel }<-\mathrm{t} \\
\text { hitung }=\mathrm{Ho} \\
\text { diterima }\end{array}$ & $\begin{array}{l}\text { Tidak ada } \\
\text { pengaruh Ruang } \\
\text { Publik terhadap } \\
\text { Kualitas Visual }\end{array}$ \\
\hline $\begin{array}{c}\text { Segmen } \\
10\end{array}$ & 0,727 & 0,529 & 0,002 & 2,160 & 3,818 & $\begin{array}{l}\mathrm{t} \text { tabel }<\mathrm{t} \text { hitung } \\
=\text { Ho ditolak }\end{array}$ & $\begin{array}{l}\text { Ada pengaruh } \\
\text { Ruang Publik } \\
\text { terhadap Kualitas } \\
\text { Visual }\end{array}$ \\
\hline $\begin{array}{c}\text { Segmen } \\
11\end{array}$ & 0,225 & 0,051 & 0,420 & $-2,160$ & $-0,833$ & $\begin{array}{l}-\mathrm{t} \text { tabel <-t } \\
\text { hitung }=\mathrm{Ho} \\
\text { diterima }\end{array}$ & $\begin{array}{l}\text { Tidak ada } \\
\text { pengaruh Ruang } \\
\text { Publik terhadap } \\
\text { Kualitas Visual }\end{array}$ \\
\hline $\begin{array}{c}\text { Segmen } \\
12\end{array}$ & 0,389 & 0,152 & 0,151 & $-2,160$ & $-1,524$ & $\begin{array}{c}-\mathrm{t} \text { tabel }<-\mathrm{t} \\
\text { hitung }=\mathrm{Ho} \\
\text { diterima }\end{array}$ & $\begin{array}{l}\text { Tidak ada } \\
\text { pengaruh Ruang } \\
\text { Publik terhadap } \\
\text { Kualitas Visual }\end{array}$ \\
\hline $\begin{array}{c}\text { Segmen } \\
13\end{array}$ & 0,206 & 0,042 & 0,462 & 2,160 & 0,758 & $\begin{array}{l}\mathrm{t} \text { tabel }>\mathrm{t} \text { hitung } \\
=\text { Ho diterima }\end{array}$ & $\begin{array}{l}\text { Tidak ada } \\
\text { pengaruh Ruang } \\
\text { Publik terhadap } \\
\text { Kualitas Visual }\end{array}$ \\
\hline $\begin{array}{c}\text { Segmen } \\
14\end{array}$ & 0,222 & 0,049 & 0,426 & 2,160 & 0,822 & $\begin{array}{l}\mathrm{t} \text { tabel }>\mathrm{t} \text { hitung } \\
=\text { Ho diterima }\end{array}$ & $\begin{array}{l}\text { Tidak ada } \\
\text { pengaruh Ruang } \\
\text { Publik terhadap } \\
\text { Kualitas Visual }\end{array}$ \\
\hline
\end{tabular}

